\title{
Principal's Leadership Behaviours Influence on Teacher's Job Satisfaction in Public Secondary Schools in Kenya
}

\author{
${ }^{1}$ Asena Muganda James ${ }^{*}{ }^{2}$ Asena Muganda David \\ ${ }^{1}$ RAF International University Faculty of Education P.O Box 884-00242 Kitengela, Kenya \\ ${ }^{2}$ Kibabii University School of Business and Economics P.O Box 1699-50200 Bungoma, Kenya
}

\begin{abstract}
The purpose of the study was to establish leadership behaviours influence on teacher's job satisfaction in public secondary schools in Bungoma North Sub County, Bungoma County, Kenya. More specifically, the study sought to establish directive, participative, supportive and achievement oriented leadership behaviours on teacher's job satisfaction. Path Goal model effectiveness formed the theoretical framework. The study adopted a descriptive survey research approach. The unit sample of the study was all the 51 secondary schools in Bungoma North Sub County. The target population comprised of all the 51 principals and 761 teachers in all the 51 secondary schools in Bungoma North Sub County. All the 51 Principals were purposively selected from the sampled schools as they were leaders in those schools. The actual sample size of 263 teachers was selected purposively, making the actual sample size of the study to be 314 respondents. Data was collected using two sets of self-administered questionnaires. Spearman rho was used to determine the degree of relationship between principal's leadership behaviours and teacher's job satisfaction. The study concluded that directive, supportive, participative and achievement oriented leadership behaviours had a significant influence on teacher's job satisfaction. Teachers also preferred directive leadership behaviours as opposed to principal's achievement oriented leadership behaviours. The study recommended policy reforms on the action plans that influence job satisfaction of teachers.
\end{abstract}

Keywords: Leadership Behaviours, Directive, Supportive, Participative, Achievement Oriented, Job Satisfaction.

\section{Introduction}

\subsection{Background of the Study}

A leader is the person who mobilizes other people to undertake collective action in pursuit of a common goal (Samuel, 2005). Principal leadership behaviours affect all schools' learning situations including teacher's job satisfaction (Hezibola, 2008; Asuquo, 2007). UNESCO (2006) and Mbiti (2007) recognized the important role played by school management in the achievement of school goals and its implications on the overall performance of both the teachers and students. The principal's leadership behaviours play an important role in determining productivity among the teachers in the school. Leadership and employee job satisfaction are two factors that have been regarded as fundamental for an organization's success, since they impact on how leaders contribute to goal attainment such as employee job satisfaction (Northouse, 2010). A capable leader provides direction for the organization and leads followers towards achieving desired goals (Mosadegh \& Yarmohammadian, 2006).

In defining various aspects of leadership and job satisfaction, Northouse (2010) ascertained that the leadership process influences thoughts and actions of followers and also establishes a favorable job satisfaction conditions. Hulpia and Devos (2009) alluded that leadership has proven to have positive effects on job satisfaction. This study attempted to investigate the relationship between leadership behaviours and job satisfaction. Path-Goal leadership theory of 1971 (cited in Martin, 2012) asserts that leadership is based on how leaders facilitate task performance on subordinates leading to job satisfaction, the indicators of which are: status, goal achievement, intrinsic valence and high performance. Jacobs (2010) affirmed that opportunities for teachers to gain leadership experience are present in schools where there is shared leadership. Furthermore, there is need for people to participate in decision making so as to develop leaders at 
all levels of the organization so as to sustain improvement, change and enhance job satisfaction (Grant, 2011).

Job satisfaction is an appraisal of the perceived job characteristics, work environment and emotional experiences at work. Sonia (2010) defined job satisfaction as a pleasurable emotional state resulting from the appraisal of one's job and attitude towards the job with factors such as recognition, supervisory practices, commitment, working climate, individual expectations and level of education. On the other hand, Kim and Kim (2008) and Joo (2011) describe teacher's job satisfaction as a positive psychological and affective reaction about teacher's present workplace, teaching profession and career experiences as a whole. Nevertheless; Path-goal theory (2012) postulated that job satisfaction is the extent to which leaders are supportive, directive, achievement oriented and participative to their employees.

Job satisfaction is determined by present workplace, teaching experiences, and self-reported information influenced by employers and policy-makers thus, teacher's job satisfaction is the extent to which teachers are satisfied with their job (Joo, 2011). Kariuki, Ndirangu, Sang and Okao (2014) established that further training, responsibility, social status and a sense of belonging has an impact on the level of morale and commitment of teachers to their duties. Satisfaction with work life among teachers translates into job satisfaction which may in turn lead to less stress, reduced turnover, high realization of the schools' goals and objectives leading to better academic performance. Studies in countries like Uganda, Tanzania, Gambia and Kenya found that many teachers were teaching not because of internal motivation but rather due to lack of other openings elsewhere (Barret, 2005; Hedges 2002). Unless this trend is checked, the country may fail to equip learners with relevant skills yet this is one of the flagship projects of Kenya Vision 2030 (Republic of Kenya, 2007; Njeru \& Orodho, 2008).

There is a high value attached to secondary school education by both the Government and parents in Kenya. At this level of education learners are prepared for advanced studies, further training and the job market. The social pillar in Kenya's Vision 2030 envisions delivery of quality education for the country to attain development. Education has one of the highest budgetary allocation in Kenya; more so in teacher's salaries. The expected output from this investment by the various education stakeholders is academic achievement. Many factors have been blamed for the low morale of teachers in public secondary schools and the resulting poor academic performance in Kenyan public secondary schools amongst them lack of facilities, student's indiscipline and an overloaded curriculum. It is however possible that those other less researched management factors such as the quality of leadership in schools may also lead to lack of job satisfaction among teachers and consequently poor academic performance. One such factor is principal's leadership behaviours which in turn affects teacher job satisfaction. When teachers are dissatisfied with their work, they may not be productive and this may eventually affect academic performance. Several studies have been done on job satisfaction (Akoth, 2011; Nadarasa \& Thuraisingain, 2014; Obina, Mbona \& Acire, 2012; King'ori, 2013) however, there appear to be few studies linking the constructs of leadership behaviours and job satisfaction in public secondary schools in Kenya. In view of this, the importance of determining the relationship between leadership behaviours and teacher job satisfaction in public secondary schools is needful. This study therefore examined leadership behaviours influence on teacher's job satisfaction in public secondary schools in Bungoma North Sub County, Bungoma County.

\subsection{Objectives of the Study}

The general objective of the study was to determine leadership behaviours influence on teacher's job satisfaction in public secondary schools in Bungoma North Sub County, Bungoma County Kenya. The specific objectives were:

1. To examine directive leadership behaviours influence on teachers' job satisfaction in public secondary schools in Bungoma North Sub County.

2. To determine supportive leadership behaviours influence on teachers' job satisfaction in public secondary schools in Bungoma North Sub County.

3. To establish participative leadership behaviours influence on teachers' job satisfaction in public secondary schools in Bungoma North Sub County. 
4. To determine achievement oriented leadership behaviours influence on teachers' job satisfaction in public secondary schools in Bungoma North Sub County.

\subsection{Research Hypotheses}

The study was guided by the following hypotheses

Ho1: Directive leadership behaviours has no significant relationship on teachers' job satisfaction in public secondary schools in Bungoma North Sub County

Ho2: Supportive leadership behaviours has no significant relationship on teachers' job satisfaction in public secondary schools in Bungoma North Sub County

Ho3: Participative leadership behaviours has no significant relationship on teachers' job satisfaction in public secondary schools in Bungoma North Sub County

Ho4: Achievement oriented leadership behaviours has no significant relationship on teachers' job satisfaction in public secondary schools in Bungoma North Sub County

\section{Literature Review}

\subsection{Path Goal Theory}

Principal's leadership styles influence on teachers' job satisfaction can be explained by Path-Goal theory. The theory was originally developed by Evans (1970) and later modified by House (1971). House made three assumptions about human behavior. First, consistent with VIE theory, subordinates are assumed to behave in a rational, self-serving manner. Second, House assumed that people are uncomfortable and experience stress in ambiguous situations. More specifically, House believed that people would seek ways to minimize role ambiguity, which refers to confusion about how certain tasks should be conducted or confusion about how role performance will be evaluated. Finally, House assumed that a reduction in role ambiguity would lead to increased subordinate satisfaction and performance enhancement. The main assumption of Path-Goal model is based on effective leaders engage in behaviors that complement subordinates' environments and abilities in a manner that compensates for deficiencies and is instrumental to subordinate satisfaction and individual and work unit performance" (House, 1996). Management scholar Robert J. House's remark about leadership concisely captures the essence of the path-goal theory of leadership. According to this theory, followers consciously consider alternative courses of action and assess the likelihood that each course of action will yield desirable as well as undesirable outcomes. After consciously considering these alternative actions, proponents of the theory propose that followers act in a manner they believe will maximize the attainment of positive outcomes while minimizing the attainment of negative outcomes. Using this conceptualization of motivated behavior, path-goal leadership theory suggests that an effective leader directs followers' behavior by changing followers' perceptions of the relationship between behaviors and outcomes.

Path-Goal theory considers four distinct types of behavior: directive path-goal clarifying, supportive, participative and achievement-oriented leadership behaviors. Directive path-goal clarifying leadership behavior is generally aimed at reducing role ambiguity, clarifying the link between follower effort and goal attainment, and linking follower goal attainment to extrinsic rewards. Supportive leadership behavior focuses on the personal needs of followers. Specific supportive leadership behaviors include making the work environment an enjoyable place and expressing concern for the personal welfare of followers. As stressed in House's initial theory, fulfillment of followers' personal needs, when tied to goal-directed effort, enhance follower motivation and performance. This performance boost is due to the reduction of stress and frustration. Reducing such negative effects is posited to result in an increased net positive valence for workrelated activities. Supportive leadership behavior would be most effective when work-related activities were not intrinsically satisfying. In such a way, a leader's behaviors can serve to complement task characteristics. Participative leadership behavior involves considering followers' input and valuing their opinions when making decisions that affect them. It is essentially a combination of directive and supportive leader behavior. House and Mitchell claimed that the impact of this type of behavior is highly contingent on follower personality. They argued that the extent to which subordinates prefer external control, as opposed to independence, moderates the effect of participative leadership. They also suggested that participative leadership behaviors would be effective when directed toward followers who prefer independence. 
Achievement-oriented behavior is also a combination of directive and supportive leadership behaviors and it's concerned with enhancing follower's performance in an almost inspirational manner. Leaders engaging in such behavior express confidence in the capability of followers to reach their goals and encourage followers to set high goals and elevate standards of excellence. The net result is an overall increase in follower's performance and satisfaction.

Robbins (2005) believes that path-goal theory is the most influential contingency approach to leadership. However, Richard et al., 2012 (cited in Malik 2013) believed that path-goal theory as the most sophisticated and comprehensive contingency theory. According to Path-Goal theory, a leader provides necessary direction and support to subordinates to achieve individual as well as organizational goals (Silverthorne, 2001). In this regard this study postulated essence of secondary school principals in providing a desired way to goal attainment by teachers. The stated goal of this leadership theory is to enhance employee performance and satisfaction by focusing on their motivation levels. The Path-Goal theory is relevant to this study because it recognizes the influence of a leader on the achievement of the organization goals. The current study sought to determine the principal's leadership behaviours influence on teachers' job satisfaction. Contingency leadership theory argues that there is no single way of leading and that every leadership behaviours should be based on certain situations, which signifies that there are certain people who perform at the maximum level in certain places; but at minimal performance when taken out of their element (Morgan, 2007).

\subsection{Leadership Behaviours}

Leadership behaviours is a pattern of behaviours leaders prefer to use (Marie \& Neal, 2011). Mosadeghrad and Yarmohammadiand (2006) defined leadership as a series of attitudes, characteristics and skills used by leaders in different situations in accordance with the individual and organizational goals. There are as many leadership approaches as there are principals. Some of these leadership behaviours include autocratic, bureaucratic, charismatic democratic situational, transactional and transformational. The current study aimed to evaluate leadership behaviours from a behavioral perspective supported by four leadership behaviours; directive, supportive, participative and achievement oriented.

\subsubsection{Directive Leadership behaviours}

Directive leadership is characterized by authoritarian and legitimate power that uses high levels of strict direction, command and close supervision to provide psychological structure and task clarity (Northouse, 2010). Directive leaders set standards of performance, set clear rules and regulations to subordinates as to what should be done and how it should be done, and the timeline when it should be completed (Jones \& George, 2011; Northouse, 2010). Additionally, directive leadership tells subordinates exactly what they are supposed to do. It characterizes a leader who tells subordinates about their task, including what is expected of them, how it is to be done, and dead line for the completion of particular task. He also sets standards of performance and defines clear rules and regulations for subordinates (Northouse, 2013). Directive leadership style is appropriate when the task is complex or ambiguous, formal authority is strong and the work group provides job satisfaction (Lussier \& Achua, 2010).

\subsubsection{Supportive Leadership Behaviours}

Supportive leadership is characterized by a leader who is friendly, approachable and treats subordinates as equals (Northouse, 2010). Besides, Supportive leaders care about the well-being and human needs of subordinates and go out of their way to make the work more enjoyable for their subordinates (Jones \& George, 2011; Northouse et al., 2010). Schools are changing towards becoming market driven giving rise to a series of issues which school leadership must respond (Pont et al., 2009). The supportive style is suitable when subordinates show lack of confidence in ability to complete a task and little motivation (Negron, 2008). Grant (2011) asserts that workers can provide valuable input into the successful leadership of school when supported and empowered. Similarly, Ingersoll (2001) discussed that school organizational factors such as lack of support from administrators, and decision-making power encouraged school teachers to leave their profession. Malik (2011) highlighted the importance of work characteristics (routine, autonomy and feedback) how the work role is defined (role conflict and role ambiguity) as well as work environment (leadership, stress, advancement, opportunities and participation) in relation to job satisfaction. This study observes that it is only fair for leaders in organizations to endow favorable work climate which support employees' aspirations. 


\subsubsection{Participative Leadership Behaviours}

As organizations become redesigned, teachers are given opportunities to be part of group decision making. Job satisfaction includes the idea that teachers' have influence and participate in school-wide decisions for staff development (Walstrom \& Louis, 2008). In addition, the expertise needed for school development must come from a broader base of individuals with diverse skills, knowledge regarding curriculum, pedagogy, decision making authority and best practices (Gronn, 2009). Participative leadership consults with subordinates about decisions, and takes their contributions into account, solicits for suggestions, opinion, obtains their ideas, shares responsibilities, involving them in the planning, execution phases and integrates their suggestions into decision making prior to making a final decision ( Leana, 2013; Northouse, 2013).To this end, participative leadership is appropriate when subordinates don't want autocratic leadership, have internal locus of control, and follower ability is high; when task is complex, authority is either weak or strong, and satisfaction from co-workers is either high or low (Lussier \& Achua, 2010). Moreover, Mat (2008) argued that participative leadership is suggested to increase the follower effort when the task is unstructured by increasing the role clarity and the follower autonomy. Participative leadership according to Lewin (as cited in Waters, 2013) states that minds of many makes better decisions than judgment of a single mind alone. In light of this observation teachers become more committed to decision making practices and are more actively involved thus job satisfaction is realized.

\subsubsection{Achievement Oriented Leadership Behaviours}

Achievement-Oriented leadership is appropriate when followers are open to autocratic leadership, have external locus of control, and follower's ability is high; when task is simple, authority is strong, and job satisfaction from co-workers is either high or low (Lussier \& Achua, 2010). This is corroborated in research study that leadership is the ability to influence a group towards the achievement of a vision or set of goals (Robbins et al., 2010). Similarly, Daft (2002) contended that leadership behavior should clarify goals and set performance standards to be achieved. Nevertheless, this study argues that achievement oriented leadership may achieve performance through recognizing, encouraging and delegating task to followers. The study largely concurs with observations made by Davis, Darling-Hammond, LaPointe and Meyerson (2005) that the growing consensus on the attributes of effective head teachers show that successful school leaders influence achievement through the support and development of effective teachers and the implementation of effective organizational processes.

Negron (2008) noted achievement-oriented style is suited for unclear tasks and subordinates who may need a morale booster to increase their confidence in ability to accomplish the given goal. Achievement oriented style is effective when work is complex and the environment uncertain. This is because it can increase subordinates' self confidence that they are able to attain the goals. The achievement oriented leader tries to change attitudes of employees so as to seek continuous improvement (Leana, 2013). However, achievement oriented leadership on the other hand is predicted to increase the follower effort and satisfaction when the task is unstructured and complex by increasing the follower self-confidence and the expectation of successfully accomplishing a challenging task or goal. This is explained in the concepts of the Path-Goal Theory where environment and the staff factors are moderators in leadership style and staff performance relationship as well as in leadership style and job satisfaction relationship (Northouse, 2013).

According to path goal theory, for leaders to be effective, they need to: recognize the needs of those they lead and try to satisfy these needs through the workplace, reward people for achieving their goals, help subordinates identify the most effective paths they need to take to reach their goals (Northhouse, 2013). This concur with assertion made by (Yukl, 2010) that achievement oriented style takes a transactional approach, which specifies expectations, clarify responsibilities, provides recognition and rewards to attain the desired performance. As Path-goal theory focused on how leaders influence followers' expectations Robert House, the originator of the theory, proposed a model in which leader behavior is acceptable when employees regard it as a source of satisfaction. In addition to this, leader behavior is motivational when it eliminates factors that hinder goal accomplishment but provides emotional support to the employees, and grants meaningful recognition in return for success. House claimed that the leader should stay on the right path to achieve challenging goals since achievement- oriented leadership is setting high standards and challenging goals for the employees by encouraging them to perform at their highest level (Northouse, 2013). Drawing 
from these suggestions, teachers' academic qualifications are successes thus need to be recognized as part of achievement in the right path towards exhibiting goal attainment.

\subsection{Leadership Behaviours Influence on Teacher's Job Satisfaction}

Leadership is expressed in terms of traits, behaviors, sources of power, and situations, in relationship to influencing followers and accomplishing objectives (Yukl, 2010). In similar context, it is how one supervises employees to improve organizational effectiveness and to influence people towards the accomplishment of goals (Marion, 2002; Yukl, 2010). However, this study perceives that the best way to influence teachers and make them effective is the interactions between the leader and followers so as realize job satisfaction. Nevertheless, an extensive amount of research has been done to investigate leadership style and job satisfaction; especially, effective leadership in order to distinguish different leadership styles that provides organizational practice with supporting theory on how to lead an organization (House, 1971; Burns, 1978; Bass, 1985; Dirks \& Ferrin, 2002). To this end effective leadership is based on many factors, such as leaders 'characteristics, leadership behavior, and related situation as important factors for administrators to implement their duties smoothly Waro 2006 (cited in Saowanee, Wallapha \& Tang 2014).

Great man and traits theorists' asserts that leaders are born and endowed with a particular personality or behavioral characteristic shared by other leaders however; behavioral theorists' affirmed leadership is based on the actions of the leader while management theorists' viewed leadership in terms of supervision of employees to improve organizational effectiveness (Marion, 2002; Yukl, 2010).Situational theorists believed that different styles of leadership may be more appropriate to use based on differences in situations and readiness levels of followers (Daft, 2002). However, school principals need to be inducted on the skills so as to effectively supervise teachers in their schools and also challenged to choose the right leadership behaviours that increases the level of motivation of teachers.

Many researchers assert that universal leadership traits, characteristics, behaviors or styles make a leader to be effective however, this might be a complicated endeavor since leaders are perceived as excellent but some could simultaneously be perceived as inefficient by others (Nathan, Leslie, Toshio \& Daniel, 2011). More so, the leader encourages change by aligning everyone in the same direction to achieve the common goals (Northouse, 2013). To this end, head teachers need to share the change process with the teachers, besides being thinkers and doers in order to direct and promote shared values and the work culture. Northouse (2010) ascertains that central to all the conceptualizations, leadership is the process whereby an individual influences a group to achieve a common goal. The understudy assert that academic education plays a critical role towards influencing teachers. Moreover; leadership is a social influence enacted by individuals in formal positions of power or leadership within an organization, such as supervisors may also have a wide remit of influence (Kelloway \& Barling, 2010). However, these processes need one with expert knowledge to direct teachers in achieving goals that bring satisfaction.

\subsection{Conceptual Framework}

Based on the analysis of literature a hypothetical model for this study was constructed. The major concern of this study is to determine principal's leadership behaviours influence on teacher's job satisfaction in public secondary schools in Bungoma North Sub County. The outcome is an improvement of the school's performance mean score or not. The independent variables are directive, supportive, participative and achievement oriented leadership behaviours. The dependent variable is teacher's job satisfaction.

\section{Research Methodology}

The study was undertaken in Bungoma North Sub County; Bungoma County, Kenya. It utilized descriptive survey research approach, because it's an approach where information on a population is gathered at a single point in time which was the case for this study. Orodho (2002) observes that descriptive survey is used in preliminary and exploratory studies to gather information, summarize, present and interpret for the purpose of clarification. It is also intended to produce statistical information about aspects of education that interest's policy makers and educators. The unit sample of the study was all the 51 secondary schools in Bungoma North Sub County in Bungoma County. The target population comprised of all the 51 principals and 761 teachers in all the 51 secondary schools in Bungoma North Sub County. All the 51 principals were purposively selected from the sampled schools as they were leaders in those schools. The formula recommended by Yamane (1967) was used to determine the actual sample size of 263 teachers making the sample size 314 . The study relied mainly on primary data which was collected through self-administered 
questionnaires. The study adopted two different sets of questionnaires for the school principals and teachers. Spearman rho was used to determine the degree of relationship between principals' leadership behaviours and teacher's job satisfaction. Spearman rho was used because it was considered appropriate technique of determining the degree of correlation between variables in case of ordinal data where ranks are given to the different values of the variables. Spearman rho correlation statistics analysis was carried out to establish relationship between achievement-oriented, directive, supportive, and participative leadership behaviours on teachers' job satisfaction as in research objectives. However, t-test hypotheses were carried out to determine whether there was significance relationship between leadership behaviours and teacher's job satisfaction.

\section{Results and Discussions}

\subsection{Directive leadership Behaviours Influence on Teacher's Job Satisfaction}

The mean of directive leadership behaviours influence on job satisfaction was obtained by taking the average of teacher's responses to all the questions under directive leadership behaviours and job satisfaction. Spearman Rank correlation coefficient was then computed for each response under directive leadership behaviours against Job satisfaction. The results are summarized in Table 4.1

\section{Table 4.1 Directive Leadership Behaviours and Teachers Job Satisfaction}

\begin{tabular}{|l|l|l|l|}
\hline & & & Directive \\
\hline Spearman's rho & $\begin{array}{l}\text { Correlation } \\
\text { Coefficient }\end{array}$ & Job Satisfaction & $.592^{* *}$ \\
\hline & & $\mathrm{n}$ & 245 \\
\hline
\end{tabular}

\section{**Correlation is significant at the 0.05 level.}

A total of 245 questionnaire responses from teachers were analyzed to derive Spearman rho correlation coefficient. Positive correlation was found (rho $(245)=0.592, \mathrm{p}<0.05$ ). This indicates a significant relationship between directive leadership behaviours and teacher's job satisfaction. This conforms to the studies of (Yilmaz 2007; Riffat-un-NisaAwan \& Bigger, 2008; Akoth 2011), which reported a positive relationship between principal directive leadership behaviours and teacher job satisfaction. Malik (2013) reveled that directive leader behaviors have significant relationship with supervision and job satisfaction in general this is in line with the finding of the understudy as directive behaviours had a positive correlation with teachers' job satisfaction.

\subsection{Supportive Leadership behaviours Influence on Teacher's Job Satisfaction}

The mean of supportive leadership behaviours influence on job satisfaction was obtained from the average of each teacher responses to all the questions pertaining to supportive leadership behaviours and job satisfaction as summarized in table 4.2.

Table 4.2 Supportive Leadership behaviours and Teachers Job Satisfaction

\begin{tabular}{|l|l|l|l|}
\hline & & & Supportive \\
\hline Spearman's rho & $\begin{array}{l}\text { Correlation } \\
\text { Coefficient }\end{array}$ & Job Satisfaction & $.708^{* *}$ \\
\hline & & $\mathrm{n}$ & 245 \\
\hline
\end{tabular}

**Correlation is significant at the 0.05 level.

Spearman rho correlation coefficient calculated for the relationship between principals' supportive leadership behaviours and job satisfaction of teachers was (rho $(245)=0.708, \mathrm{p}<.0 .05$ ) which is highly significant. Supportive leadership behaviour had a highly positive correlation $\left(0.708^{* *}\right)$. Research on supportive leadership has been premised on management leadership styles (Lenka, 2012; Musera, Achoka \& Mugasia, 2012) leaving a behavioral gap yet teacher job satisfaction is attributed to attitudes. The studies were also conducted outside Kenya. There was need therefore to carry out the current study to rule out 
geographical and cultural differences. The study by Lenka (2012) was premised on the Path Goal Theory like the current one. The findings also concurred that where there was a supportive principal, teachers enjoyed their job. The principal using supportive leadership behaviours displays considerate behaviours thus reducing the uncertainties of the work. Nguni, Slegger \& Densen (2006) concurred with the current findings that transformational or supportive leadership behaviours, had strong moderate behaviours on job commitment.

\subsection{Participative Leadership Behaviours Influence on Teacher's Job Satisfaction}

The mean for participative leadership behaviours influence on job satisfaction was obtained from the average of 245 teacher responses. Spearman Rank correlation coefficient computed was found to be significantly positive (rho $(\mathrm{n}=245)=0.364, \mathrm{p}<0.05)$. The results indicated a positive correlation $(0.364 * *)$ between participative leadership behaviours and teacher's job satisfaction summarized in Table 4.3. The findings of the current study concur with those of Robinson (2008); Monyazi (2012); Ndarasa and Thuraisingam (2014); Ndiku et al (2009); Sigalai (2010); Mwangi (2013); Obina,et al (2012) and Kingori (2013) that participative leadership behaviours positively affected teachers job satisfaction.

\section{Table 4.4 Participative leadership behaviours and Teachers Job Satisfaction}

\begin{tabular}{|l|l|l|l|}
\hline & & & Participative \\
\hline Spearman's rho & $\begin{array}{l}\text { Correlation } \\
\text { Coefficient }\end{array}$ & Job Satisfaction & $.364 * *$ \\
\hline & & n & 245 \\
\hline
\end{tabular}

\section{**Correlation is significant at the 0.05 level.}

\subsection{Achievement Oriented Leadership Behaviours Influence on Teacher's Job Satisfaction}

The mean of the achievement oriented behaviours influence on job satisfaction were obtained by taking the average of the teacher responses to all the questions under this leadership behaviours and job satisfaction for each of the respondent. Spearman Rank correlation coefficient was then computed and preferred since the original data was based on ranks. The results of the findings are summarized in Table 4.4.

Table 4.4 Achievement Oriented behaviours and Teacher's Job Satisfaction

\begin{tabular}{|l|l|l|l|}
\hline & & & Achievement Oriented \\
\hline Spearman's rho & $\begin{array}{l}\text { Correlation } \\
\text { Coefficient }\end{array}$ & Job Satisfaction & $.445 * *$ \\
\hline & & n & $\mathbf{2 4 5}$ \\
\hline
\end{tabular}

**Correlation is significant at the 0.05 level.

Spearman rho correlation coefficient of (rho $(245)=0.445, \mathrm{p}<0.05)$ was found. The findings indicate that there is a significant relationship between principals' achievement oriented leadership behaviours and teacher's job satisfaction with a positive correlation coefficient $\left(0.445^{* *}\right)$. The findings of the current study concur with those of Gatere (1998), Obina (2012) and Njeri (2011) that a significant positive relationship exists between the level of teacher job satisfaction and the strength of the leadership behaviours dimensions of achievement orientation.

\subsection{Leadership Behaviours Influence on Teacher's Job Satisfaction}

Leadership behaviours influence on teacher's job satisfaction indicated in Table 4.5 depicts that Achievement leadership behaviours had a higher correlation of 0.504 for principals as compared to 0.445 for teachers. Directive leadership had a higher correlation of 0.592 for teachers than head teachers'. Supportive leadership indicated coefficient correlation almost similar with teachers having slightly higher correlation than the principals. This implies that there was mutually understanding on achievement of goals by the two groups however; participative leadership behaviours had the lowest correlation for teachers. Both categories had Supportive leadership behaviours with 0.708 and 0.749 respectively for teachers and principals 
indicating a positive relationship. This was the highest correlation therefore; supportive leadership had high job satisfaction compared to other leadership behaviours. This implies that supportive leadership strategy was effective in influencing teacher job satisfaction. On contrary, participative leadership style was less preferred by teachers despite the effort that principals continued practicing this behaviours. This indicates that active participation was not regularly utilized by both principals and teachers. Directive leadership behaviours practiced by the principals was preferred indicating that teachers wanted to be controlled to perform tasks based on specific directive. Similarly, achievement leadership style was less preferred by the teachers in spite of the principal 's input. This means that teachers were not well prepared to achieve the desired set goals on high performance and thus a paradigm shift on leadership towards followers and situations is needful

The findings supported those of earlier studies by and Ngwala (2014)and Rambo (2013) which stated that a leader may adapt and even combine various leadership behaviours to fit different situations. The samples used in Mosadegharad and Yarmohammadian (2006) study were similar to the one used in the current study in terms of the level of schooling .Thus, irrespective of cross-cultural differences and study locations, principal were found to be eclectic in their use of leadership behaviours .The situation determines the behaviours or combination of behaviours the principal adopts. However, the reviewed studies (Roul, 2012; Ngwala 2014; Odundo \& Rambo, 2013) were skewed towards administrative leadership leaving a behavioral gap. The findings of the reviewed literature concur with the current study's findings that principals may use different leaderships sometimes and at other times use a mix of different leadership approaches.

\subsection{Leadership Behaviours Influence on Teacher's Job Satisfaction}

\begin{tabular}{|l|l|l|}
\hline Leadership Behaviours & \multicolumn{1}{|c|}{ Job Satisfaction } & \\
\hline & Teachers & Principals \\
\hline & rho Value & rho Value \\
\hline Directive & 0.592 & 0.442 \\
\hline Supportive & 0.708 & 0.749 \\
\hline Participative & 0.364 & 0.456 \\
\hline Achievement Oriented & 0.445 & 0.504 \\
\hline
\end{tabular}

\subsection{Research Hypotheses Testing}

Ho1: Directive leadership behaviours has no significant relationship on teachers' job satisfaction in public secondary schools in Bungoma North Sub County. The calculated t value was -3.790 at $95 \%$ level of significance, with 244 degree of freedom and a p-value $=0.0002<0.05$. Thus the null hypothesis was rejected on the basis of sample data. From this it can be concluded that there was a significant relationship between directive leadership behaviours and job satisfaction as viewed by respondents.

Ho2: Supportive leadership behaviours has no significant relationship on teachers' job satisfaction in public secondary schools in Bungoma North Sub County. The calculated t value was -5.947 at $95 \%$ level of significance with 244 degree of freedom. The p-value was $0.000<0.05$. The null hypothesis was rejected on the basis of sample data. From this it can be concluded that there was a significant positive relationship between supportive leadership behaviours and job satisfaction.

Ho3: Participative leadership behaviours has no significant relationship on teachers' job satisfaction in public secondary schools in Bungoma North Sub County. The calculated t value was -20.707 at $95 \%$ level of significance, with 244 degree of freedom. The p-value was $0.000<0.05$. The null hypothesis was rejected on the basis of sample data. From this it can be concluded that there was a significant relationship between participative leadership behaviours and job satisfaction as viewed by respondents. 
Ho4: Achievement oriented leadership behaviours has no significant relationship on teachers' job satisfaction in public secondary schools in Bungoma North Sub County. The calculated t value was -12.945 at $95 \%$ level of significance, with 244 degree of freedom. The p-value was $0.0000<0.05$. The null hypothesis was rejected on the basis of sample data. From this it can be concluded that there was a significant relationship between achievement oriented leadership behaviours and job satisfaction.

\section{Conclusions}

The results of this study presented some evidence of the existence of the hypothesized relationship between leadership behaviours and teacher's job satisfaction. All the four leadership behaviours were found to have significant positive relationship with teacher's job satisfaction. Directive leadership was not preferred by experienced teachers while it is useful to inexperienced teachers seeking direction. Supportive leadership, being a caring approach, appeals to teachers when they need belongingness. Since participative leadership involves teachers in discussions it gives teachers ownership of decisions made in the school. Although achievement oriented leadership pushes and demands results from teachers but when the principal gives confidence in the teacher's ability here is reassurance. Applied appropriately, each behaviours has its place in giving teachers job satisfaction for the expected students' learning outcomes

\section{References}

[1.] Akoth, M. (2011). Influence of Head Teachers' Leadership Styles on Job Satisfaction among Public Primary School Teachers in Migori District. Unpublished Thesis: University of Nairobi. Kenya.

[2.] Barret, M. (2005). Teacher Accountability in Context; Tanzanian Primary School Teachers' Perception of Local Community and Education Administration. Journal of Comparative and International Education, 35(1), 43-61.

[3.] Davis, S., Darling-Hammond, L., LaPointe, M., \& Meyerson, D. (2005). School Leadership Study: Developing Successful Principals. Stanford, CA: Stanford University, Stanford Educational Leadership Institute.

[4.] Daft, R.L. (2005). The Leadership Experience. (3rd Ed.). Thomson- Southwestern, Vancouver.

[5.] Grant, C. P. (2011). Dissertation on the Relationship between Distributed Leadership and Leadership Effectiveness: North Carolina State University.

[6.] Gronn, P. (2009). Leadership Configuration. Leadership journal. 5(3), 381-391.

[7.] Hedges, J. (2002). The Importance of Posting and Interaction with the Education Bureaucracy in Becoming a Teacher in Ghana. International Journal of Education Development. 22(3-4), 353-366.

[8.] House, R. J. (1971). Path-goal Theory of Leadership: Lessons, Legacy, and a Reformulated Theory. Leadership Quarterly, vol.7 (1996), 323-352.

[9.] House, R, J., \& Mitchell, T. R. (1974). Path-Goal Theory of Leadership. Journal of Contemporary Business, 3, 81-98.

[10.] Jacobs, G. E. (2010). Relationship between Distributed Leadership as Practiced by Principals and the Organizational Commitment of Teachers. PhD Dissertation, Southern University. Georgia.

[11.] Joo, Y. H. (2011). The Structural Analysis of the Effects of Distributed Leadership on Teacher Professionalism. A Dissertation Presented to University of Texas, Austin. December, 2011.

[12.] Jones, G., \& George, K. (2011) Contemporary Management. New York: McGraw-Hill.

[13.] Judge, T. A., Parker, S., Colbert, A., Heller, D., \& Ilies, R. (2001). Job satisfaction: Across cultural review. In N. Andersen, D. S. Ones, H. K. Sinangil, \& C. Viewesvaran (Eds.), Handbook of industrial, work and organizational psychology: Vol. 2. Organizational Psychology (pp.2552). London: Sage.

[14.] Kariuki, K.W.A; Ndirangu, M., Sang, K. A., \& Okao, M. E. (2014). Secondary School Teacher's Perceptions of the Factors that Influence their Morale and Commitment to Work: A case of Nakuru County. International Journal of Innovation and Applied. 9(4), 1589-1597.

[15.] Kingee ori, G. (2013). Influence of Secondary School Principals' Leadership styles on Teachers' Job Satisfaction: A Study of Embu County-Kenya. Thesis. Kenyatta University.

[16.] Lussier, R. N., \& Achua, C. F. (2010). Leadership. (4th Ed.), South-Western Cengage Learning: Mason, USA.

[17.] Marie,T. \& Neal, M. (2011). Emotion and Attribution of Intentionality in Leader Member Relationships. U. of Queensland UQ Business School. 
[18.] Marion, R. (2002). Leadership in Education; Organizational Theory for the Practitioner. New Jersey: Pearson Education, Inc.

[19.] Malik, H. S. (2013). Relationship between Leader Behaviors and Employees' Job Satisfaction: A Path-Goal Approach. Journal of Commerce and Social Sciences. 7 (1), 209-222.

[20.] Martin, R. (2012). Path goal Theory of Leadership Encyclopedia of Group Process and Intergroup Relations. Thousand Oaks, CA: SAGE Publications.

[21.] Mat, J. (2008). The Influence of Leadership Style on Internal Marketing in Retailing. Unpublished $\mathrm{PhD}$ thesis, University of Stirling.

[22.] Mbiti, M, (2007). Foundations of School Administration. New York: Oxford University Press McShane, S., \& Glinow, M. (2005). Organizational Behavior. USA: The McGraw- Hill Companies.

[23.] Mosadegh Rad, A. M., \& Yarmohammadian, M. H. (2006). A Study of Relationship between Managers' Leadership Style and Employees' Job Satisfaction. Leadership in Health Services. 19 (2), 11-28.

[24.] Monyazi, N. (2012.) Job Satisfaction of Primary School Teachers in Botswana. T, University of Botswana, Gaborone.

[25.] Musera, G., Achoka, K. (2012). Perceptions of Secondary School Teachers on Principal's Leadership Styles in School Management in Kakamega District, Kenya: Implications for Vision 2030. International Journal of Humanities and Social Science. 2 (6). 27-47.

[26.] Mwangi, J. (2013). Effects of Leadership Styles on Teachers' Job Performance and Satisfaction: A case of Public Secondary Schools in Nakuru County, Kenya. Unpublished Thesis University of Nairobi.

[27.] Nadarasa, T., Thuraisingham,R.(2014). The Influence of Principals' Leadership Styles on School Teacher's Job Satisfaction- Study of Secondary Schools in Jaffna District. International School of Scientific and Research Publications.

[28.] Ndiku, J., Mualuko, M., Simiyu A., Achoka, A. \& Judy, K. (2009). Improving Decision-making in Schools through Teacher Participation. Educational Research and Reviews, 4(8), 391-397.

[29.] Nguni, S., Sleegers, P. \& Denessen, E. (2006). Transformational and Transactional Leadership Effects on Teachers' Job Satisfaction, Organizational Commitment and Organizational Citizenship Behaviour in Primary Schools: The Tanzanian Case, School Effectiveness and School Improvement 17(2): 145-77.

[30.] Negron, D. (2008). A case study examining the relationship of the path-goal theory leadership styles to profits in El Paso, Texas, Rent-A-Center stores. PhD Dissertation Capella University.

[31.] Ngwala, K. (2014). Influence of Principals' Leadership Styles on Secondary Schoolteachers' Job Satisfaction in Kangundo District, Kenya. Unpublished Thesis. Kenyatta University.

[32.] Njeru. K. \& Orodho, J. (2008). Technique of Writing Research Proposals and Reports in Education and Social Sciences. Nairobi; Masola publisher.

[33.] Northouse, P. G. (2010). Leadership: Theory and practice (5th Ed.). Thousand Oaks, CA: Sage.

[34.] Northouse, P. (2013). Leadership Theory and Practice. Thousand Oakes: Sage Publications, Inc.

[35.] Obina, S. Mbona, N. Acire, J. (2012). Head teachers' leadership Styles and Teachers' Job Satisfaction in Uganda, Rwanda Burundi, Tanzania and Kenya. Unpublished Thesis University of Nairobi.

[36.] Odundo, A., \& Rambo, C. (2013). Influence of Leadership Styles Adopted by public secondary school principals on Teachers Motivation: The Case of Nyanza Province, Kenya. International Journal of Disaster Management and risk Reduction. 5(1).

[37.] Owalabi, A. (2006). Relative Influence of Gender and Working Experience on Job Satisfaction of Primary School Teachers. The Primary School Educators. 1(1), 86-89.

[38.] Riffat-un-NisaAwan \& Bigger,S. (2008). Monitoring the Quality of Secondary Education in the context of Decentralization in Pakistan. Bulletin of Education Research: Institute of Education \& Research.

[39.] Robbins, S. P. (2005). Essentials of Organizational Behavior. New Jersey: Prentice Hall.

[40.] Samuel, G. (2005). The relationship between Leadership and Internal Customer Satisfaction within a Motor Manufacturing Company in Gauteng. 
[41.] Sonia, J. (2010). Organizational Commitment and Job Satisfaction: A Study of Employees in the Information Technology Industry in Bangalore, India. Dissertation Submitted in Christ University, Bangalore.

[42.] Saowanee, S., Wallapha, A., \& Tang, K. N. (2014). The Impact of Leadership Styles of School Administrators on Affecting Teacher Effectiveness. Elsevier ltd. Procedia-Social and Behavioral Sciences 186 (2015) 1031-1037.

[43.] Silverthorne, C. (2001). A test of the path-goal leadership theory in Taiwan. Leadership and Organization Development Journal, 22(4), 151-158.

[44.] Street, G. W. (2011). Engaging Staff in the Development of Distributed Leadership. PhD Dissertation. Washington State University.

[45.] The Wallace Foundation (2009). Assessing the effectiveness of school leaders: New directions and new processes. New York: Author.

[46.] Yilmaz, S. (2007). "The Relationship between Organizational Trust and Organizational Commitment in Turkish Primary Schools". World Applied Sciences Journal 3 (5), 775-78.

[47.] Yukl, G. (2010). Leadership in Organizations. (7th Ed.). New Jersey: Pearson Education Inc. 